\title{
Comparison of Morphological, AFLP and SSR Markers for the Protection of Eggplant Germplasm
}

\author{
J. Prohens, J.E. Muñoz-Falcón, S. Vilanova and F. Nuez \\ Instituto de Conservación y Mejora de la Agrodiversidad Valenciana \\ Universidad Politécnica de Valencia \\ Camino de Vera 14, 46022 Valencia \\ Spain
}

Keywords: Almagro, diversity, fingerprints, landraces, Listada de Gandía, Spanish Black

\begin{abstract}
Germplasm of local materials of vegetable crops can be protected in several ways, by registering it as a conservation variety, or also by means of a Protected Designation of Origin (PDO) or Protected Geographical Indication (PGI) status. An effective protection requires devising tools to characterize and distinguish the materials from other related or similar materials. Here, we study the utility of morphological and molecular characterizations for the protection of eggplant (Solanum melongena) germplasm. In this respect, we have made morphological and molecular (AFLP and SSR) characterizations in Spanish local materials of eggplant corresponding to three varietal groups with different characteristics: Almagro (protected by a PGI status), Listada de Gandía (internationally known striped local variety), and Spanish Black (conglomerate of different local varieties from different origins). Morphological data are useful to distinguish the local landraces from related materials. However, within each varietal group there is some morphological variation among the different germplasm accessions of each group, and also there is variation in the morphological characterization among trials performed in different years. The use of AFLP and SSR markers has confirmed the existence of genetic variation within each group. In this respect, SSRs are more reliable than AFLPs to distinguish closely related eggplant materials and have allowed detect specific universal SSR markers for the Almagro and Listada de Gandía landraces. Correlation coefficients between distances based on morphological, AFLP and SSR markers are moderate, reflecting the different genetic information provided by these three markers. The results show that morphological and molecular markers provide complementary information, and when used in combination can be very useful for the protection of local materials of eggplant.
\end{abstract}

\section{INTRODUCTION}

Germplasm enhancement can be achieved by using it as a source of variation in breeding programmes for developing new varieties, or by using it per se for obtaining high quality or speciality products with high added value. In this latter case, the germplasm used mainly corresponds to local varieties or landraces which are reputed for having a high organoleptic and/or nutritional quality, or that are associated with special production processes (Sequi et al., 2007; Muñoz-Falcón et al., 2009a). In this respect, for a satisfactory enhancement of the germplasm for this type of use, it is necessary to develop tools that allow the differentiation and protection of the plant material.

In the European Union, protection of local varieties can be achieved through a conservation variety status (Commission of the European Communities, 2008), or in the case of agricultural products with specific characteristics associated to a high quality and originating from a certain geographical region by a Protected Designation of Origin (PDO) or a Protected Geographical Indication (PGI) (Commission of the European Communities, 2006a, b). The main difference between PDO and PGI is that in PDO the final product must be produced, processed and prepared in a certain geographical area using recognized knowledge, while in the PGI it is just required that at least one of the stages of production, processing or preparation has a link with a certain geographical area. 
On many occasions, the production of PDO or PGI products requires the use of local varieties with special characteristics that are essential for achieving a high quality.

Morphological and molecular characterizations of the local varieties can be of great utility to develop tools that allow the protection of the germplasm. In this respect, we have worked with three different Spanish local materials of eggplant (Solanum melongena L.) that differ in their characteristics: Almagro, Listada de Gandia, and Spanish Black.

The Almagro eggplant is the only eggplant officially protected in Europe with a PGI status, which was granted in 1994 (Castro, 2005). The Almagro eggplant is an heirloom landrace from the center of Spain used for making pickles. Almagro materials are characterized by having small fruits covered by an acrescent and prickly calyx (Muñoz-Falcón et al., 2009a). On occasion, pickling eggplants from the neighbouring region of Andalusia (Pickling Andalusian) are used instead of the Almagro landrace because of the higher yield and lower prickliness of the former. However, these Pickling Andalusian materials give a low quality product, as the internal texture of the processed pickled fruits is soft, and this is an undesirable characteristic for Almagro PGI eggplants (Prohens et al., 2007).

The Listada de Gandia eggplant is another heirloom from the Mediterranean coast of the region of Valencia, and is native to the countryside around the city of Gandía, which is situated $70 \mathrm{~km}$ south of Valencia. Listada de Gandia fruits have obovate to oblong shape and white background colour covered by narrow purple stripes (MuñozFalcón et al., 2008). The Listada de Gandía is internationally known for its white flesh, excellent texture and cooking quality. Listada de Gandía eggplant materials might be candidates for being registered as a conservation variety or for being granted a PDO or PGI status. However, there are many striped varieties of eggplant, which on many occasions are being sold as Listada de Gandia and do not correspond to the authentic Listada de Gandia materials.

The Spanish Black eggplants correspond to a group of local varieties with different origins and with different shapes and sizes, and which are characterized for having uniformly coloured black skin (Muñoz-Falcón et al., 2009b). This type of local eggplant with black skin is having an increased demand for several reasons, including the fact that consumers are used to this typ black colored type of eggplant, and that anthocyanins giving the black color are reported to present healthy properties (Noda et al., 2000). Protection of the group of Spanish Black eggplants as a whole with a PDO or PGI status does not seem realistic, as it includes many different types of eggplants from different origins. However, some of these local varieties could be granted a conservation variety status.

Morphological characterizations allow descriptions of the phenotypic characteristics of the plant material and, currently, morphological traits constitute the tools used for the distinctness, uniformity and stability (DUS) tests required for protection of plant materials (UPOV, 2002). Despite their evident usefulness, morphological traits may be subject to environmental variation and require the cultivation of plants. In this respect, molecular markers represent an additional tool for protecting and characterizing the plant material.

In this paper we present the results obtained with morphological and molecular (AFLPs and SSRs) characterizations of Almagro, Listada de Gandia and Spanish Black eggplants and the implications for the protection of local materials of this crop.

\section{MATERIALS AND METHODS}

\section{Trials and Plant Material}

Three characterization trials were performed in open field cultivation during three consecutive years. Each of the characterization trials was focused on comparing morphological and molecular (AFLP and SSR) markers for the protection of Almagro, Listada de Gandia and Spanish Black eggplants. Each of these trials was labeled as ALM, 
LDG and SBL, respectively. Reference groups representing materials with different origins, but with similar characteristics to each of the target groups (Pickling Andalusian, Non-Listada de Gandia Striped, and Non-Spanish Black eggplants, respectively for the ALM, LDG and SBL trials) were also included in the trials. Apart from these reference groups, control materials which, for each trial, did not conform to the characteristics of the target and reference groups and which allowed comparison of the results between trials were also used in each of the experiments.

The number of accessions of each of the target, reference, and control groups for each of the trials is shown in Table 1, and ranged between 33 (LDG trial) and 44 accessions (SBL trial) and represented the diversity of each of these groups. The Pickling Andalusian materials correspond to local materials of this Spanish landrace; the NonListada de Gandia Striped are Spanish and non-Spanish materials of local and commercial varieties of the striped type; the Non-Spanish Black includes non-Spanish local materials as well as commercial varieties.

\section{Morphological Characterization}

Morphological characterization was mostly based on the descriptors elaborated by the European Eggplant Genetic Resources Network (EGGNET) (Prohens et al., 2005; van der Weerden and Barendse, 2007), although for each of the trials some ad hoc additional descriptors specially suited for the varietal groups considered were included. The number of descriptors used for each trial was 14 for the ALM, 35 for the LDG and 37 for the SBL trials, respectively.

\section{Molecular Characterization}

Genomic DNA from each accession was extracted from young leaves. For the AFLP molecular study, three combinations of primers were used in the selective amplification for each of the trials: E-ACT + M-CTA, E-ACG + M-CTA, and E-ACG + M-CAA. For the SSR characterization, the numbers of SSRs used for each trial were: 36 for the ALM trial, 14 for the LDG trial and 14 for the SBL trial. Some of these SSRs were developed by our group, while others were developed by Stàgel et al. (2008) and Nunome et al. (2003a, b).

\section{Data Analysis}

For the morphological traits, the mean values were calculated for each accession in each of the trials and pairwise Euclidean distances among individual accessions were calculated. For the AFLP and SSR data, genetic distances were calculated using the Dice similarity coefficient. Multivariate principal component analysis (morphological traits) or principal coordinates analysis (molecular data) were performed using the distance data (Mohammadi and Prasanna, 2003). Correlations between morphological, AFLP and SSR distances were calculated using the Pearson correlation coefficient.

\section{RESULTS}

\section{Morphological Characterization}

In each of the trials, target and reference groups could be clearly distinguished by a number of morphological descriptors from control groups (data not shown). When considering the target groups (Almagro, Listada de Gandia, and Spanish Black) and reference groups (Pickling Andalusian, Non-Listada de Gandía Striped, and Non-Spanish Black, respectively), we found morphological differences among accessions within each of the groups, which is reflected in values different from zero for the mean Euclidean distance among accessions. However, in all cases, the distances within groups were lower than the distances between groups (Table 2).

In the ALM trial, the range of values for the Almagro and Pickling Andalusian accessions overlapped for 11 out of 14 of the morphological descriptors studied. Only for the descriptors fruit pedicel width at the proximal end (smaller in Almagro), fruit calyx 
prickles (more in Almagro), and fruit calyx length (shorter in Almagro), the range of variation between Almagro and Pickling Andalusian accessions did not overlap. In the LDG trial, the range of variation for the Listada de Gandia overlapped with those of the Non-Listada de Gandia Striped materials for 33 out of the 35 descriptors used. The only descriptors for which no overlap between these groups was found were the fruit weight (higher in Listada de Gandía) and fruit puncture force (lower in Listada de Gandia). For the SBL trial, the Spanish Black materials showed a considerable morphological variation, as they included materials from different origins and characteristics. As expected, all traits overlapped for the 34 descriptors studied with those of Non-Spanish Black materials from other origins and no morphological traits specific of the Spanish Black eggplants were found.

Although few or no (in the case of the Spanish Black accessions) single descriptors allowed accessions belonging to the different groups to be distinguished, the combined use of several descriptors used allowed the accessions of the target groups to be distinguished from the reference groups. However, the comparison of morphological characterizations in different trials made on the same accessions using the same sets of descriptors showed that there is an important environmental variation in the characterization results. In this respect, when comparing the results of the principal components analysis of the 10 accessions that were included in both the LDG and SBL trials (Fig. 1) we found that although, in general, a single accession evaluated in different years tends to plot in the same area of the principal components graph, sometimes one accession grown in year 1 plots closer to a different accession grown in a year 2 .

\section{AFLP Characterization}

The number of AFLP fragments detected with the three combinations of primers used was of 112 (ALM trial), 109 (LDG trial) and 146 (SBL trial). In all cases, the percentage of polymorphic markers was very similar, ranging from 22.3 to $35.6 \%$ for the ALM and SBL trials, respectively. If we exclude the controls, the percentage of polymorphic loci for the target plus reference groups is $6.5 \%$ for the ALM trial, $18.2 \%$ for the LDG trial, and $28.4 \%$ for the SBL trial. As occurred for the morphological traits, the AFLP-based genetic distances revealed the existence of genetic diversity within each of the groups. It also showed that the mean genetic distances within each group were smaller than the mean genetic distances between the target and its reference groups (Table 2).

For each of the trials, AFLP markers allowed fingerprints specific of each accession to be obtained except in the case of the LDG trial, where in the Listada de Gandia group, two accessions on one side, and two others on the other, shared the same AFLP fingerprint. No AFLP markers specific and universal to all the Almagro, Listada de Gandia, or Spanish Black materials were found.

Principal coordinates analysis applied to AFLP markers showed that the Almagro and Pickling Andalusian eggplants are clearly differentiated from the fresh consumption eggplants, although both groups share a common genetic background and present a low degree of genetic differentiation. Also, the Listada de Gandia accessions can be differentiated from control accessions, but some Non-Listada de Gandia Striped accessions plot in the same area of the principal coordinates graph. Spanish Black materials were intermingled with the rest of Non-Spanish Black materials, showing that they present an important source of diversity and a broad genetic background.

\section{SSR Characterization}

The percentage of polymorphic SSR fragments clearly depended on the type of materials used. In this respect, for the ALM trial, which only included SSR characterization of the Almagro and Pickling Andalusian accessions and did not include the controls, the percentage of polymorphic loci was $22.2 \%$. On the contrary, for the LDG and SBL trials, which included the target and reference groups as well as controls that did not belong to the groups investigated, the percentage of polymorphic loci was $92.9 \%$ and $100 \%$, respectively. For each of the trials, SSR markers identified fingerprints specific to 
each accession. Contrary to what occurred for AFLPs, we found two SSR markers specific and universal to all the Almagro materials, and two SSR markers specific to the Listada de Gandia materials. As expected, due to its diversity of origins and characteristics, no SSR fragments specific and universal to all Spanish Black eggplants were found.

Here, we also found that the SSR-based genetic distances revealed the existence of genetic diversity within each of the groups, and that the average genetic distances within each group was smaller than the average genetic distances between the target and its reference groups (Table 2).

Principal coordinates analysis applied to SSR markers showed that with this type of marker, the Almagro and Pickling Andalusian groups can be clearly distinguished from each other. The same occurs in the LDG trial, in which the Listada de Gandia accessions are clearly separated from the Non-Listada de Gandia Striped and control accessions. As expected, the Spanish Black materials were intermingled in the principal coordinates plot with the Non-Spanish Black materials, indicating important diversity and a broad genetic background.

\section{Correlation between Traits}

Correlations between the three types of markers were always of positive sign, but the values were low or moderate, and not always significant (Table 2). In this respect, the number of significant correlations varied depending on the trial. For example, the morphological-AFLP correlations only were significant for the SBL trial, while the morphological-SSR correlations were significant for the three trials. AFLP-SSR correlations were significant for the LDG and SBL trials, but not for the SBL trial.

\section{DISCUSSION}

Certification of authenticity and protection of germplasm is of great utility for enhancing and giving added value to local varieties (Sequi et al., 2007; Piergiovannoni and Laghetti, 1999). Certification of the authenticity of the materials is essential if the standards of quality are to be ensured (Rao et al., 2006; Trichopolou et al., 2007). The study of the diversity, relationships and establishment of genetic fingerprints of the materials used is necessary. In this respect, several complementary tools, like morphological and molecular markers, can be used.

Morphological traits are currently used as the basis for DUS tests (UPOV, 2002) and allow descriptions of differences in traits that are of agronomic interest. In our trials, morphological characterizations of eggplant, which usually are based in a considerable number of traits, many of which refer to the fruit (Prohens et al., 2005; van der Weerden and Barendse, 2007), have allowed the description of the materials. Also, in the cases of the Almagro and Listada de Gandía eggplants, we have found specific morphological descriptors for which the range of variation between these local materials and the morphologically similar (but of different origin) materials Pickling Andalusian and NonListada de Gandia Striped did not overlap. In this respect, these descriptors can be used as key traits to identify the local varieties and distinguish them from related materials. However, as has been found in other eggplant studies (Prohens et al., 2004), morphological traits are subjected to environmental variation, and it is difficult to establish absolute ranges of values for discriminating traits, as these traits may be vary among years or among different fields of crop cycles in the same year.

AFLP and SSR markers have been extensively used for the characterization of eggplant germplasm (e.g., see Daunay, 2008). Here, they have proven to be useful for the characterization of the eggplant germplasm. While AFLPs have been used to study overall genetic variation and relationships among the different groups studied, they did not allow a clear distinction between the materials belonging to the target and reference groups and no AFLP fragments specific and universal to the accessions of the target groups could be found. SSRs, on the other hand, allowed a clear separation of the Almagro and Listada de Gandia groups from the Pickling Andalusian and Non-Listada de Gandia Striped groups, 
respectively, and specific and universal SSR marker have found for the target groups. Compared to AFLPs, SSRs have the ability to detect differences in materials that share a common genetic background, as well as to determine relationships based on specific traits (Bredemeijer et al., 2002; Tam et al., 2005). However, despite the advantages of SSRs in this respect, these markers were not been able to establish a genetic fingerprint of the Spanish Black eggplants, probably because these materials do not correspond to a single landrace, but to a conglomerate of different landraces that only share their skin colour (Muñoz-Falcón et al., 2009b).

Correlations between distances obtained with morphological, AFLP, and SSR characterizations were low to moderate, indicating that they sample different levels of diversity and that the information obtained among them is complementary and useful for the enhancement and protection of the material (Staub et al., 1996). Morphological markers sample traits that are controlled by many genes, AFLPs mostly detect point mutations, and SSRs are specific to hypervariable loci (Powell et al., 2006; Giancola et al., 2002). Interestingly, correlations between morphological and SSR distances were significant in the three trials performed, while morphological and AFLP distances significant in only one of the trials, which may suggest that in the materials studied, SSRs are more related than AFLPs to genetic differences that cause differences in the genotype and reveal better the evolution occurred within the crop (Giancola et al., 2002).

\section{CONCLUSIONS}

Enhancement and protection of eggplant local landraces requires characterizing and obtaining specific fingerprints of the materials to be protected. Here, we have found that morphological, AFLP and SSR markers provide complementary information for the characterization of different Spanish local eggplant materials. In particular, morphological and SSR characterizations were useful for obtaining specific fingerprints of local materials like the Almagro and Listada de Gandía eggplants. This kind of information can be used as a tool for promoting the protection of local vegetable varieties with a PDO or PGI status.

\section{ACKNOWLEDGEMENTS}

This contribution was financed by the "Ministerio de Ciencia e Innovación" grants AGL2006-04878/AGR, AGL2009-07257, and RF2008-00008-00-00.

\section{Literature Cited}

Bredemeijer, G.M.M., Cooke, R.J., Ganal, M.W., Peters, R., Isaac, P., Noordijk, Y., Rendell, S., Jackson, J., Röder, M.S., Wendehake, K., Dijcks, M., Amelaine, M., Wickaert, V., Bertrand, L. and Vosman, B. 2002. Construction and testing of a microsatellite database containing more than 500 tomato varieties. Theor. Appl. Genet. 105:1019-1026.

Castro, A. 2005. Berenjena de Almagro, algo único. Asociación para la Promoción de la Indicación Geográfica Protegida Berenjena de Almagro. Bolaños de Calatrava, Ciudad Real, Spain.

Commission of the European Communities. 2006a. Council Regulation (EC) No. $509 / 2006$ of 20 March 2006 on agricultural products and foodstuffs as traditional specialities guaranteed. Offic. J. Eur. Union L93:1-11.

Commission of the European Communities. 2006b. Council Regulation (EC) No. $510 / 2006$ of 20 March 2006 on agricultural products and foodstuffs as traditional specialities guaranteed. Offic. J. Eur. Union L93:12-25.

Commission of the European Communities. 2008. Commission Directive 2008/62/EC of 21 June 2008 providing for certain derogations for acceptance of agricultural landraces and varieties which are naturally adapted to the local and regional conditions and threatened by genetic erosion and for marketing of seed and seed potatoes of those landraces and varieties. Offic. J. Eur. Union L162:13-19.

Daunay, M.C. 2008. Eggplant. p.163-220. In: J. Prohens and F. Nuez (eds.), Handbook of 
plant breeding: Vegetables II. Springer, New York, USA.

Giancola, S., Marcucci Poltri, S., Lacaze, P. and Hopp, H.E. 2002. Feasibility of integration of molecular markers and morphological descriptors in a real case study of a plant variety protection system for soybean. Euphytica 127:95-113.

Mohammadi, S.A. and Prasanna, B.M. 2003. Analysis of genetic diversity in crop plants Salient statistical tools and considerations. Crop Sci. 43:1235-1248.

Muñoz-Falcón, J.E., Prohens, J., Vilanova, F. and Nuez, F. 2009b. Diversity in commercial varieties and landraces of black eggplants and implications for broadening the breeders gene pool. Ann. Appl. Biol. 154:453-465.

Muñoz-Falcón, J.E., Prohens, J., Vilanova, F., Ribas, F., Castro, A. and Nuez, F. 2009a. Distinguishing a protected geographical indication vegetable (Almagro eggplant) from closely related materials with selected morphological traits and molecular markers. J. Sci. Food Agric. 89:320-328.

Muñoz-Falcón, J.E., Prohens, J., Vilanova, S. and Nuez, F. 2008. Characterization, diversity, and relationships of the Spanish striped (Listada) eggplants: a model for the enhancement and conservation of local heirlooms. Euphytica 164:405-419.

Noda, Y., Kneyuki, T., Igarashi, K., Mori, A. and Packer, L. 2000. Antioxidant activity of nasunin, an anthocyanin in eggplant peels. Toxicology 148:119-123.

Nunome, T., Suwabe, K., Iketani, H. and Hirai, M. 2003b. Identification and characterization of microsatellites in eggplant. Plant Breed. 122:256-262.

Nunome, T., Suwabe, K., Ohyama, A. and Fukuoka, H. 2003a. Characterization of trinucleotide microsatellites in eggplant. Breed. Sci. 53:77-83.

Piergiovannoni, A.R. and Laghetti, G. 1999. The common bean landraces from Basilicata (southern Italy): an example of integrated approach applied to genetic resources management. Genet. Res. Crop. Evol. 46:47-52.

Powell, J.W., Morgante, M., Andre, C., Hanafey, M., Vogel, M., Tingey, S.V. and Rafalski, A. 1996. The comparison of RFLP, RAPD, AFLP and SSR (microsatellite) markers for germplasm analysis. Mol. Breed. 2:225-238.

Prohens, J., Blanca, J.M. and Nuez, F. 2005. Morphological and molecular variation in a collection of eggplant from a secondary center of diversity: implications for conservation and breeding. J. Amer. Soc. Hort. Sci. 130:54-63.

Prohens, J., Blanca, J.M., Rodríguez-Burruezo, A. and Nuez, F. 2004. Spanish traditional varieties of eggplant: diversity and interest for breeding. Proc. XIIth EUCARPIA Meeting Genet. Breed. Capsicum eggplant. Noordwijkerhout, The Netherlands, 17-19 May 2004. p.38-43.

Prohens, J., Muñoz-Falcón, J.E., Vilanova, S., Castro, A., Ribas, F. and Nuez, F. 2007. Participatory breeding in eggplant: selection and improvement for quality and yield in a local landrace. p. 221-230. In. K. Niemirowicz-Szczytt (ed.), Progress in research on Capsicum \& eggplant. Warsaw University of Life Sciences, Warsaw, Poland.

Rao, R., Corrado, G., Bianchi, M. and Di Mauro, A. 2006. (GATA)4 DNA fingerprinting identifies morphologically characterized 'San Marzano' tomato plants. Plant Breed. 125:173-176.

Sequi, P., Dell'Abate, M.T. and Valentini, M. 2007. Identification of cherry tomatoes growth origin by means of magnetic resonance imaging. J. Sci. Food. Agric. 87:127132.

Stàgel, A., Portis, E., Toppino, L., Rotino, G.L. and Lanteri, S. 2008. Gene-based microsatellite development for mapping and phylogeny studies in eggplant. BMC Genomics 9:357.

Staub, J.E., Gabert, A. and Wehner, T.C. 1996. Plant Variety protection: a consideration of genetic relationship. HortScience 31:1086-1091.

Tam, S.M., Mhiri, C., Vogelaar, A., Kerkveld, M., Pearce, S.R. and Grandbastien, M.A. 2005. Comparative analyses of genetic diversities within tomato and pepper collections detected by retro-transposon based SSAP, AFLP and SSR. Theor. Appl. Genet. 110:819-831.

Trichopolou, A., Soukara, S. and Vasilopoulou, E. 2007. Traditional foods: a science and 
society perspective. Trends Food Sci Technol. 18:420-427.

UPOV. 2002. General introduction to the examination of distinctness, uniformity and stability and the development of harmonized descriptors of new varieties of plants. International Union for the Protection of New Varieties of Plants. Geneva, Switzerland.

van der Weerden, G.M. and Barendse G.W.M. 2007. A web-searchable database developed for the EGGNET project and applied to the Radboud University Solanaceae database. Acta Hort. 745:503-506.

\section{Tables}

Table 1. Plant materials used for the 'Almagro' (ALM), 'Listada de Gandía' (LDG) and 'Spanish Black' (SBL) trials, including the number of accessions used in parenthesis.

\begin{tabular}{lccc}
\hline Trial & Target group & Reference group & Controls \\
\hline ALM & Almagro landrace & Pickling Andalusian landrace & Non-pickling materials \\
& $(18)$ & $(15)$ & $(10)$ \\
LDG & Listada de Gandia landrace & Non-Listada de Gandia Striped & Non-striped materials \\
& $(5)$ & materials (15) & $(13)$ \\
SBL & Spanish Black landraces & Non-Spanish Black materials & Non-black materials \\
& $(9)$ & $(29)$ & $(6)$ \\
\hline
\end{tabular}

Table 2. Mean Euclidean distances (morphological traits) and genetic distances (AFLP and SSR markers) within the target groups (Almagro, Listada de Gandia, and Spanish Black) and between the target and reference (Pickling Andalusian, Non-Listada de Gandia Striped, and Non-Spanish Black) groups.

\begin{tabular}{|c|c|c|c|c|c|c|}
\hline \multirow[t]{2}{*}{ Target group } & \multicolumn{2}{|c|}{ Morphological } & \multicolumn{2}{|c|}{ AFLPs } & \multicolumn{2}{|c|}{ SSRs } \\
\hline & $\begin{array}{l}\text { Target } \\
\text { group }\end{array}$ & $\begin{array}{l}\text { Reference } \\
\text { group }\end{array}$ & $\begin{array}{l}\text { Target } \\
\text { group }\end{array}$ & $\begin{array}{l}\text { Reference } \\
\text { group }\end{array}$ & $\begin{array}{l}\text { Target } \\
\text { group }\end{array}$ & $\begin{array}{l}\text { Reference } \\
\text { group }\end{array}$ \\
\hline \multicolumn{7}{|c|}{ ALM trial } \\
\hline Almagro & 4.41 & 6.16 & 0.050 & 0.067 & 0.168 & 0.790 \\
\hline \multicolumn{7}{|c|}{$L D G$ trial } \\
\hline Listada de Gandia & 8.02 & 10.10 & 0.004 & 0.027 & 0.266 & 0.586 \\
\hline \multicolumn{7}{|c|}{ SBL trial } \\
\hline Spanish Black & 7.08 & 7.44 & 0.034 & 0.040 & 0.440 & 0.439 \\
\hline
\end{tabular}


Table 3. Correlation between distances obtained with morphological traits, AFLP and SSR markers for each of the trials.

\begin{tabular}{lcl}
\hline & Morphological & AFLP \\
\hline AFLP & $0.131 \mathrm{~ns}$ ALM trial & \\
SSR & $0.340^{* * *}$ LDG trial & $0.101 \mathrm{~ns}$ \\
& $0.024 \mathrm{~ns} \quad 0.326 * *$ \\
AFLP & $0.377^{* * *}$ SBL trial & \\
SSR & $0.448^{* * *}$ & $0.381 * * *$ \\
AFLP & $0.349^{* * *}$ & \\
SSR & &
\end{tabular}

\section{Figures}

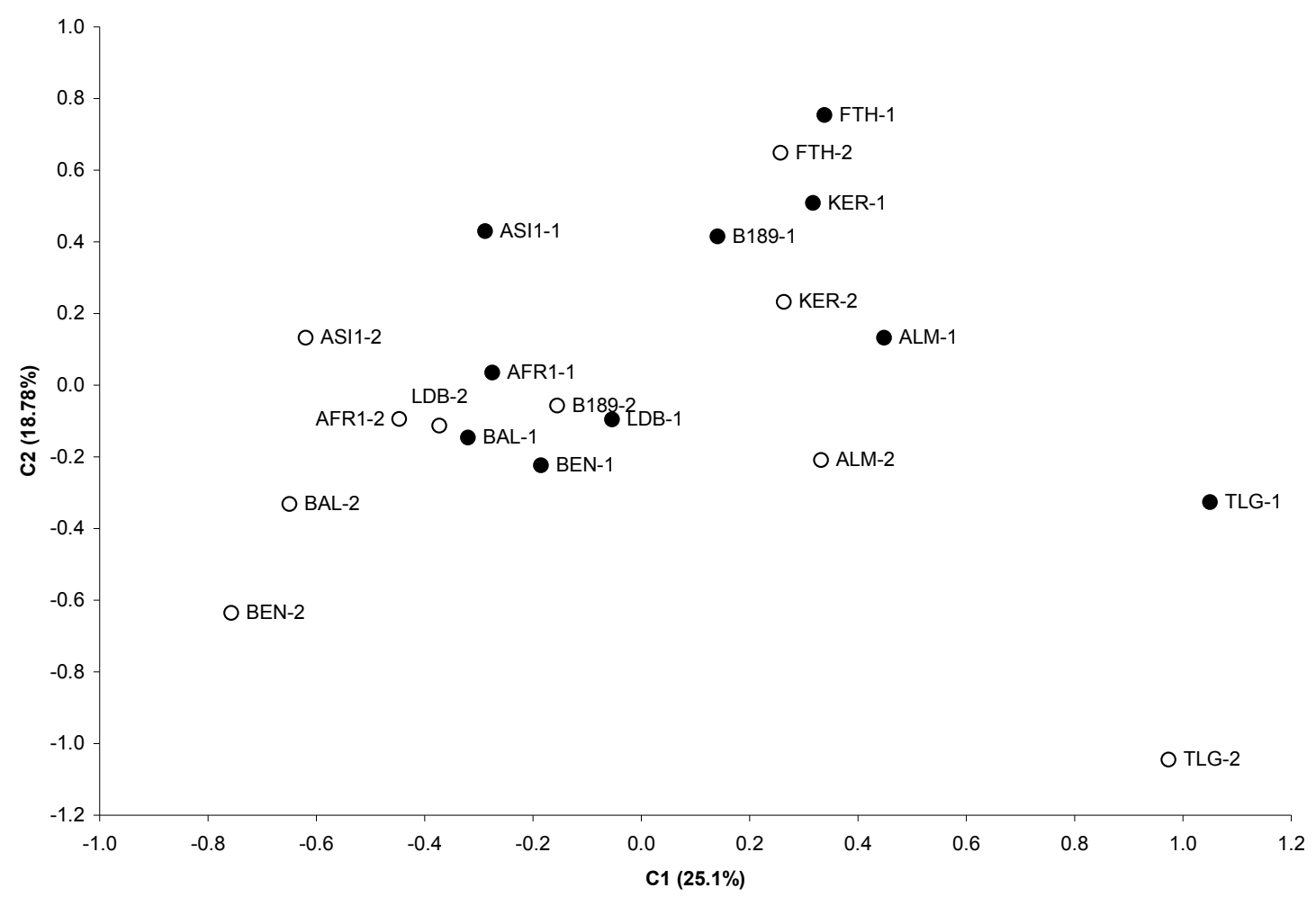

Fig. 1. Comparison of 10 accessions morphologically characterized in two different years according to principal components analysis. Accessions characterized in the first year are represented by solid black circles and indicated by the code of the accession (three letters) followed by "-1"; Accessions characterized in the second year are represented by open white circles and indicated by the code of the accession followed by "-2". 
